\title{
Regional Autonomy Dynamics in The Reformation Era: Transitioning the Authority of Environment Policies in Central Java Province
}

\author{
Nunik Retno $\mathrm{H}^{1 . *}$ and Yuwanto ${ }^{1}$ \\ ${ }^{1}$ Department of Governmental Sciences, Faculty of Social and Political Sciences, Universitas Diponegoro
}

\begin{abstract}
Based on Law 23 of 2014 on Regional Government, there is a change in the distribution of affairs in the management of education. Secondary education (SMA / SMK) previously administered by regency / municipality government based on the law is the authority of its management to switch to provincial government. This article will discuss how the process of execution of transfer of authority of secondary education from regency / municipality government to Central Java Provincial Government. Using qualitative research, this article will provide a critical analytical understanding of the transition process or the delegation of secondary education authorities in the areas of Asset, Human Resources (HR) and Finance from the Regency / City government to the Provincial Government in Central Java. The research findings show that the delegation of authority at the level of the Provincial Government actually makes the model of government farther away from idealism to provide services closer to the community. Because the implementation of this policy impact on local government policy, which has been eliminating education for 12 years, ie from elementary school to high school. As a result of the transfer of management function to the province, now the free education policy for SMA and SMK had to stop as well as happened in Kudus, Sukoharjo, Karanganyar. The community hopes the Central Java Provincial Government still holds a commitment to free education, both for public and private schools for high school / vocational high school level. In addition, there is hope from the community for the Provincial Government to implement a commitment not to withdraw fees, levies or donations after the transfer of education authority to the Central Java provincial government.
\end{abstract}

Keywords: Regional Autonomy; Decentralization; Authority.

\section{Introduction}

The history of regional autonomy in Indonesia is very interesting to be studied and studied more deeply, especially when the change from the period of the new order regime which is central to the period of reform which finally gave birth to the decentralization model which is marked with the issuance of Law No. 32 of 2004 on Regional Government. The discussion on regional autonomy is very strong by discussing the issue of the distribution of power vertically within a country. In this system, state power will be divided between 'central government' on the one hand, and 'local government' on the other. When the government changed from the New Order era to the local government reform era directly given eleven mandatory authority to be implemented. In the implementation of regional autonomy, the regional government has the authority to organize all matters handed over by the central government, with the principle of a unitary state meaning not contrary to central government policy.

The implementation of regional autonomy not only diverts the burden and responsibility to the regions but also diverts the various authorities and rights controlled by the central to the regions. In fact, to manage the autonomy agenda, local governments and local communities are empowered with the support of facilities and funds needed to support the implementation of the regional autonomy policy as appropriate.

The problem that will be the focus of this research is how the process of transition or delegation of secondary education authority in the field of Asset, Human Resources (HR) and Finance from the Government of Regency / City to the

\footnotetext{
*Corresponding author: nunikretno92@gmail.com
} 
Provincial Government in Central Java and what impacts and implications of the transfer of authority of secondary education in Central Java Provincial Government?

The results of this research will give birth to some scientific concepts which in turn will contribute to the development of governmental science especially in relation to the implementation of Decentralization and Regional Autonomy. At the praxis level, this research can serve as guidance and input for Central Java Provincial Government in implementing Policy from Central Government. The social benefits of this research are expected to provide explanation and assurance to the teachers of SMA / SMK or the community related to the transfer of authority to manage the SMA / SMK in Central Java Province.

\section{Methodology}

The boundaries of the concept of decentralization are expressed by many government experts. Differences in the viewpoint of experts lead to definite limits on the concept of decentralization difficult to obtain. The United Nations, as cited by[1], provides that decentralization is "decentralization refers to the transfer of authority away from the national capital wheter by deconcentration (i.e. delegation) to field office or by devolution to local authorities or local bodies".

From this definition, there is a process of transferring power from the national capital with two variations: (1) through deconcentration (delegation) to the official of the vertical institution in the region or (2) through devolution (transfer of responsibility) of power to a government that has authority over a particular region or autonomous institutions in the region.

Other definitions define decentralization as a process of transferring governmental power and its functions are differentiated into (1) deconcentration ie the power and function of government are administered administratively to the central vertical institutions of the central government in the region and (2) devolution ie the power and functions of government are given to the government loca that has power in certain areas in the bonds of a country to create an autonomous region [2]

There is no single definition of decentralization, but many definitions put forward by experts. But in broad outline there are two definitions of decentralization, namely from the perspective of administration and political perspectives[3]. From an administrative perspective, decentralization is defined as the transfer of administrative responsibility from the central to local governments. Here decentralization is actually another word of decocentration. According to Parson, deconcentration is the sharing of power between members of the same ruling group having authority respectively in different areas of the state. Here there is no real transfer of authority, the subordinate only exercises authority on behalf of his boss and is accountable to his superiors[4].

In a political perspective, Smith in Lili Romli says decentralization is the transfer of power, from top level to lower level, in a territorial hierarchy, which can be one of government within a state, or officers within a large organization[5]. There is a devolution of powers, not just delegates.

From the above explanation can be seen the difference between these two perspectives lies in the definition of the definition of decentralization itself. The political decentralization perspective defines decentralization as a devolution of power from the central government to local governments. The goal of decentralization here is to bring about democratization at the local level as political equality, local accountability, and local sensitivity. While the administrative decentralization perspective defines decentralization as a delegation of administrative authority, from the central government to the local government. Here the main goal of decentralization is more emphasis on efficiency aspects of local government administration and economic development in the region.

\section{Discussion}

The basis for the regulation of the implementation of the transition of inventory and verification of P3D data (Personnel, Equipment (Assets), Financing and Documents) of secondary education in Central Java Provincial Government, among others Law No. 23 of 2014 Section 404, dated October 2, 2014. Then Circular Letter of Home Affairs 120/253 / SJ, dated January 16, 2015. Then, Governor Circular Letter no. 421.3 / 001011, dated January 26, 2915. Subsequently, SE Dirjen Dikdasmen Kemendikbud RI. 3603 / D / DM / 2015, dated August 21, 2015.

Based on Article 404 of Law 23/2014, the handover of personnel, sarpras / assets and documents (P2D) as a result of the division of authority affairs is done no later than 2 years since promulgated. Furthermore, SE Minister of Home Affairs 120/253 / SJ instructs that the Inventory of P3D shall be held no later than 31st March 2016 and the handover of P2D can be implemented no later than 2 October 2016 to formulate the RKPD, KUA / PPAS and the Regional Planning draft on APBD 2017.

From the asset side, there will be asset transfer of SMA / SMK from Kabupaten Kota to Province. With the transfer of education management function will have an impact on the process of monitoring and monitoring of school assets. Very likely, in this context, will not be maximized. Because, personally from the Provincial Education Department is not necessarily sufficient and can cover the entire upper secondary education 
institutions in Central Java. Data in the field shows the number of SMA in Central Java in 2014 is 897 consisting of SMAN 358 and SMA Private 539. While for SMK there are 1429 consists of 219 SMK Negeri and 1.210 Private SMK.

In terms of human resources, all teachers and educators in SMA / SMK will be under the responsibility of the Provincial Government, including their;/. employment status, certification process, and; management of the Principal Benefit of Educators (TPP). It is conceivable how the Central Java Provincial Government will be preoccupied with the complexity of personnel administration. Because the data in the field shows that the number of civil servant teachers there are 21,679 people consisting of 12,419 high school teachers and 9,260 teachers of SMK. For non civil servant teachers there are 36,811 consisting 10,204 high school teachers and 26,607 teachers of SMK. Thus there are 58,490 teachers of SMA / SMK status of civil servants and non civil servants.

In the field of Finance, there is a diversion of regional spending. Constraints are still complicated in the transition of senior high school and vocational high schools from district / municipality governments to provincial governments in Central Java. The transition was not followed by the change of General Allocation Fund from the Central Government. Central Java Provincial Government in APBD 2017 has increased the budget for Education and Culture with total reached $\mathrm{Rp} 4,519$ trillion. The budget has increased compared to the previous year. In pure APBD 2016, education affairs allocated Rp 485.60 billion. While the cultural affairs allocated Rp 95.60 billion. The community hopes the Central Java Provincial Government still holds a commitment to free education, both for public and private schools for high school / vocational high school level. The example is the existance of natural schools that developing environment-based alternative education in Indonesia. Natural schools are schools that use the environment outside of school as an arena for learning and interacting with the community. Just like in Semarang with their natural school called Ar Ridho.

The research findings show that the delegation of authority at the level of the Provincial Government actually makes the model of government farther away from idealism to provide services closer to the community. Because the implementation of this policy impact on local government policy, which has been eliminating education for 12 years, ie from elementary school to high school. As a result of the transfer of management function to the province, now the free education policy for SMA and SMK had to stop as well as happened in Kudus, Sukoharjo, Karanganyar.

After approximately 10 years of implementation of Law no. 32 of 2004 on Regional Government, there have been several problems in Indonesia's increasingly complex and dynamic governance, especially the problems in local government regarding the implementation of decentralization and regional autonomy. The easiest problem to look at in relation to decentralization and autonomy in autonomous regions is the emergence of small kings in every local government. Such perceptions make every local government more difficult to coordinate so that many regional developments are inconsistent with central development or lack of local government loyalty to any task or order given by the central government to local governments.

Law Number 23 Year 2014 concerning Regional Government was made with the consideration that Law Number 32 Year 2004 regarding Regional Government is no longer in accordance with the development of state, state administration and demands of local government administration so that it needs to be replaced. This revision is essential to accelerate the success of decentralization, and to realize clean, democratic local government, and to improve the welfare of the people.

Based on Law 23 of 2014 on Regional Government, there is a change in the distribution of functions in the management of education between the central government, provincial government, and district / city governments. Secondary education (SMA / SMK) previously administered by regency / municipality government based on the law is the authority of its management to switch to provincial government.

The purpose of this transfer of authority is basically so that local governments can be more focused in improving the quality of education. District / city governments can focus on improving basic education, Early Childhood Education (PAUD) and Community Education (Dikmas). Pemkab / pemkab expected to take care of this optimally and maximally. While the provincial government can prioritize its secondary education. In addition, the provincial government is also expected to complete the program launched by the central government, namely Compulsory Learning (fair) 12 Years[6]

However, there are pros and cons to the policy of transferring the authority. The reason, so far the authority of secondary education management conducted by districts / cities is considered not experiencing significant constraints. Even many districts / cities are able to provide good and free secondary education. Some districts reject the transfer of high school / vocational high schools to provinces but must still be subject to constitutional mandates.

\section{Conclusion}

The community hopes the Central Java Provincial Government still holds a commitment to free education, both for public and private schools for high school / vocational high school level. In 
addition, there are expectations from the community that the commitment does not attract fees from public schools, charges or donations remain applied after the transfer of education authority to the Central Java provincial government. The spirit of compulsory education of 12 years, then Central Java Province is expected to facilitate the operational needs of schools outside the BOS (Operational Cost School) from the center.

In the financial sector, budget sharing between provincial and district / municipal governments in Central Java is required, so it is not only charged to provincial or district / municipal governments only. Education budget policy is expected not only allocated for TPP Educators and civil servants and honorary civil servants in public schools but also for private high school / vocational school teachers.

\section{References and Notes}

1. E. Koswara, Otonomi Daerah untuk Demokrasi dan Kemandirian Rakyat, Yayasan Pariba, Jakarta (2004).

2. S. Harris, Desentralisasi dan Otonomi Daerah, LIPI Press, Jakarta (2005).
3. H. Syarif, Refleksi Otonomi Daerah dan Tantangan ke Depan, Pustaka Quantum, Jakarta (2000).

4. H. Syarif and B. Hoessein, Desentralisasi dan Otonomi Daerah: Perspektif Teoritis dan Perbandingan, in Samsuddin Haris (ed), Paradigma Baru Otonomi Daerah, P2P, Jakarta (2000).

5. L. Romli, Potret Otonomi Daerah dan Wakil Rakyat di Tingkat Lokal, Pustaka Pelajar, Yogyakarta (2007).

6. A. Rohman and T. Wiyono, Education Policy in Decentralization Era, Pustaka Pelajar, Yogyakarta (2010).

7. L. Moleong, Metode Penelitian Kualitatif, Rajawali, Jakarta (1999).

8. Sugiyono, Metode Penelitian Kuantitatif dan Kualitatif dan $R$ \& $D$, Alfabeta, Bandung (2009).

9. M. Akbal, Harmonisasi Kewenangan Antara Pemerintah Pusat Dan Daerah Dalam Penyelenggaraan Otonomi Daerah, Jurnal Supremasi, 6, 2, Oktober 2016, ISSN 1412517X (2016).

10. G. T. Ardika and Sahrul, Konsep Dasar Otonomi Daerah dalam Era Reformasi, GaleCSwara, 5, 1, Februari 2011 (2011). 